\title{
ARTICLE \\ Exploration and Research on English Linguistics Teaching Based on the Perspective of Constructivism
}

\section{Danping Yan}

Zhejiang Pharmaceutical College, Ningbo, Zhejiang, 315101, China

\begin{tabular}{l}
\hline ARTICLE INFO \\
\hline Article history \\
Received: 11 June 2019 \\
Revised: 1 July 2019 \\
Accepted: 9 October 2019 \\
Published Online: 16 October 2019 \\
\hline
\end{tabular}

Keywords:

English teaching

Constructivism

Teaching exploration and research

\section{Introduction}

$\mathrm{C}$ onstructivism is China's current educational philosophy. Its basic ideas are divided into teaching concept and learning concept, as well as student view and teacher view. Its main purpose is to reflect the characteristics of students as the main body. In this theory, teachers are also redefined. Teachers are the promoters of students' exploration of knowledge, and they are the promoters of students' independent thinking and creativity, therefore, under certain environmental influences, students can use the help of the outside world and use the corresponding materials to acquire knowledge through meaning construction. In this case, the constructivist teaching model overturns the traditional Chinese teaching model, which helps students to

\section{ABSTRACT}

In the current education system in China, the English major is an important part of the education system. As the exchanges between China's and foreign countries have deepened, the importance of English education has become more prominent. Therefore, it is of great significance to improve students' ability to use spoken English. However, as far as the teaching model in China's current universities and colleges is concerned, there are still many problems, and there is an urgent need for optimization and rectification. Based on this, this paper is based on the theory of constructivism, and deeply explores the solution to the problem of the current China's English linguistics teaching model and hope this paper can provide a meaningful reference for China's English education

define their own goals and guide students to actively learn independently and to make full use of the students' own potential. The constructivist teaching model also puts forward that the individual initiative and coordination of students is an inevitable factor for students' self-growth. It is very important to transform students from passive acceptance to active exploration; at the same time, this theory is different from traditional Chinese teaching thoughts and learning concepts, and therefore has important guiding significance for China to change traditional teaching ideas. ${ }^{[1]}$

\section{Discussion on the Current Situation of En- glish Teaching Linguistics in China}

Firstly, at present, many universities and colleges in China

*Corresponding Author:

Danping Yan,

Zhejiang Pharmaceutical College, Ningbo, Zhejiang, No. 888, East Section of Yinxian Avenue, 315101, China;

E-mail:ydp707@163.com.

Fund Project:

The 2019 Ningbo Philosophy and Social Science Project: Research on the Linkage between "Core Competence" and Public Foundation Courses__ Taking University and College English as an Example (Project No.: G19-ZC07). 
are influenced by traditional educational concepts, and most of them are dominated by instructors. The students are often memorized for the content of the teacher's lectures, and because the students' foundations are uneven, the teachers cannot set the direction of the lectures according to the actual situation of the students, causing the students to lose interest in the study. Secondly, because the textbook outline is out of touch with the actual application, the practical application is not strong, and most colleges over-emphasize the memorization of words and sentences, while ignoring the practicality of language English practice. Thirdly, at present, most of the classrooms in China lack interactivity, and teachers mostly lead the whole classroom. Students accept passively and cannot form interesting interactions. Finally, most colleges use the scores of the exams to judge the pros and cons of the students' ability, and the evaluation system is single. Such situations severely limit the students' sense of innovation and autonomy, and are not conducive to the students' actual English language application ability. ${ }^{[2]}$

\section{Discussion on the Existing Problems in En- glish Teaching Linguistics in China's Univer- sities and Colleges}

\subsection{Chinese Universities and Colleges Pay Too Much Attention to Theoretical Teaching in En- glish Education}

Due to the inadequacy of English teaching theory in most universities and colleges in China, the teaching effect is relatively poor. Judging from the China's current education model, most universities and colleges teach the content of English teaching linguistics, generally according to the textbook outline, and most of the lecturers pay too much attention to theoretical teaching, failing to live the conceptualized language knowledge in the textbook. And the general instructors pay attention to grammar in the classroom but look down upon practice. In addition, the English textbooks in most China's universities and colleges are based on "Linguistics: A Course Book" edited by Hu Zhuanglin and "A New Concise Course on Linguistic for Students of English" edited by He Zhaoxiong. ${ }^{[3]}$ The content of such textbooks is relatively difficult, and the content of the textbooks is deep and the terminology is too much. This situation also brings many difficulties to the students, thus losing interest and confidence in learning. At the same time, most students think that test scores are more important than language theory, so most students just learn too much grammar and ignore the practical use of English language.

\subsection{The Teaching Model of China's Universities and Colleges Is Dominated by Teachers}

Affected by the traditional education model, at present, China's classrooms are dominated by teachers, and the instructors are instructed to inculcate students. The teacher fully understands and absorbs the textbooks, and then interprets the textbooks on the podium, while the students passively accept the theoretical knowledge and terminology in the textbooks. In such cases, the dominant position of the teachers squeezes the students' subjectivity in the classroom, and also limits the communication and interest between the teachers and students, students and students in the overall classroom. It also makes students unable to memorize and understand the content of the course well, and more restricts the actual use of the language application of students.

\subsection{The Teaching Model Is Backward in China's Universities and Colleges}

In part of China's universities and colleges, school leaders are not very concerned about English teaching linguistics, and they still do not have enough knowledge about the importance and practical application of teaching. As a result, the college did not have enough enthusiasm and motivation for the reform of English language teaching. In addition, most of the universities and colleges are teacher-led, and some of the teachers' teaching models are too rigid, which makes the classroom lose flexibility. According to relevant surveys, one-third of the students in Chinese universities have lost their interest in linguistics because the teaching methods taught by the teachers are too tedious. Therefore, the students in the colleges and universities have only stayed on the surface of the language of English education, but cannot deeply explore and understand them.

\subsection{There Are Defects in the Student Ability Eval- uation System in China's Universities and Col- leges}

In China, the evaluation of the proficiency of students' ability is mostly judged by the examination model. In addition, most of the instructors will focus on the examination content during the teaching process, and will pay more attention to the basic knowledge of words, sentences, phonetic symbols, etc., instead of guiding students to develop in an all-round way. This situation makes the students and parents only pay attention to the test results, cannot really understand the true meaning of the English language. At the same time, the single evaluation system also caused students to not comprehensively develop. Therefore, under the constructivism, it is important to establish a sound evaluation system. 


\subsection{Lack of Interactivity in the Classroom be- tween the Teacher and Students in China's Uni- versities and Colleges}

There is another problem under China's current education model. It is the lack of interaction between the teacher and the student. Because of the single model of teaching, teachers occupy a dominant position, so that students cannot communicate effectively with teachers, and most teachers only explain what they think is difficult to understand, and the problems that students do not understand cannot be well answered. It can only passively accept the content taught by the teacher, which makes the students' participation feel extremely, and cannot give full play to the creativity of the students. At the same time, due to the uneven foundation of the students, the teachers cannot pay close attention to each individual student, but only explain the places that the teachers themselves think are difficult to understand, so that the individual differences of the class students are larger. Moreover, due to the development of the network, multimedia English is gradually becoming common in the classroom, but its model makes the content of the teacher's lesson preparation derailed from the actual application, and cannot effectively adjust the students in time, thus affecting the effect of the lecture.

\subsection{The Talent Cultivation in China's Universities and Colleges Is Inefficient}

Because China's talent cultivation does not vary from person to person and students have different abilities. Some teachers usually pay too much attention to cultivating students with better learning ability. There is not much attention paid to students with relatively poor grades. At the same time, most teachers focus on the teaching of basic words and grammar for students, but they cannot practice their oral English very well, which has led many students to form Chinese-language English in practical language applications, which does not achieve good practical results. At a certain level, it embodies the defects of the traditional Chinese education model, which makes most colleges and universities unable to cultivate practical talents for the society, most of which are paper-based, and this situation has led to the emergence of talents.

\section{Discussion on the Reform Ideas of English Language Teaching in China's Basic Perspec- tive of Constructivism}

\subsection{China's Universities and Colleges Should Make Innovations on Teaching Concepts}

The purpose of constructivism theory is to take students as the leading factor and acquire knowledge in social activities. Therefore, there is a conceptual content that is difficult to understand in English language textbooks. Teachers should take the essence and go to the dregs in the traditional teaching model. Fully liberate its solidification ideas and update teaching views. To achieve the consensus between leaders and teachers to form reform teaching. And put these consensuses into the actual teaching model, thus changing the defects brought by the traditional teaching concepts. The teachers may also actively listen to students' opinions, ask students for suggestions, and change the curability of the classroom. Based on the patterns and methods that students like, they will continue to innovate teaching methods. Based on this approach, not only can students improve their comprehensive quality, but also improve the communication between teachers and students, enhance the professional ability of the instructors, and accelerate the comprehensive development of China's teacher industry. ${ }^{[4]}$

\subsection{Highlight the Dominant Position of Students in the Classroom}

Influenced by China's traditional thinking, students from all levels, from primary school to university, are passive to accept knowledge in the classroom. And constructivism puts forward the student-led thinking, based on this idea, which fully influences China's current education model reform. Therefore, in the universities and colleges, the lecturers should also explain the language knowledge and the basic theory, as well as the flexibility of designing the classroom to increase the practicality of the students' English application language. Based on this, students' creativity and enthusiasm can be fully utilized. In order to improve students' motivation for learning English language and achieve student-led practical results. And teachers can play some Chinese and foreign anime, movies, songs and other materials in the classroom according to their hobbies and interests, improve the interaction of the classroom and enrich their content; Teachers can carry out the second class. The students are small teachers, and the students' thoughts lead the whole classroom, providing students with practical foundations and displaying individual students' platforms, thus improving the students' comprehensive quality and confidence in learning. ${ }^{[5]}$

\subsection{China's Universities and Colleges Should Car- ry out Practical Reforms for Teaching Models}

Based on the traditional Chinese education concept, teachers are dominant, and the teaching mode and educational thinking are relatively backward. The idea of constructiv- 
ism just broke the traditional Chinese education concepts. Therefore, the instructor should be based on the current situation. Therefore, the instructor should increase the practicality of the English language for the students based on the current situation, based on the teaching materials and changing the backward model of teaching. Students can lay a good foundation for oral communication in the future under the premise of regulating the pronunciation and intonation. Since English is the first common language in the world, fluent oral English is not only a manifestation of the individual ability of students, but also a bonus skill for entering social work in the future. Therefore, cultivating students is not only mainly about the ability to write and do, but also better to communicate and speak based on the teaching materials. The purpose of teacher teaching is to help students master the correct pronunciation and intonation of English. Let their students freely express their ideas. Do practical and effective communication, thereby deepening the construction concept. ${ }^{[6]}$

\subsection{China's Universities and Colleges Need to Es- tablish a Sound Evaluation System}

Since China's universities and colleges pay more attention to the test results, they ignore the evaluation in the learning process. The English-based language subject is a subject that is deeply combined with theory and practice. Most universities and colleges often only judge the individual ability of individual students by the test results, and such kind of evaluation is not comprehensive enough. Such a situation will only lead to the students' memorization of the content of the textbook, only to have a good score in the exam, and ignore the actual application of the English language. Therefore, a perfect evaluation system should be established in China's universities and colleges, and applied to the actual teaching, so that more than single examination paper tests, but also the daily learning status of students and the application of actual oral English, to achieve a fair and open assessment. In turn, students not only pay attention to the study of theoretical knowledge, but also pay more attention to the practice of everyday English language. ${ }^{[7]}$

\subsection{It Is Necessary to Increase Classroom Interac- tion in the Process of Teaching}

At present, in the China's learning environment, most teachers prepare lessons before class, and then teach on the podium. Finally, students blindly accept, which makes students lack interest in learning. Based on constructivism teaching models, the establishment of fun classrooms, increasing the effective interaction between students and students, students and teachers, can quickly improve students' interest and enthusiasm for learning. At the same time under the guiding ideology of the theory, creating a new interactive education model can greatly improve the teaching effect of English language. First of all, we can create a model of exploration in the classroom. Teachers point to the students, and they explore and communicate with themselves. They find their own inadequacies in the exploration and solve their own problems through communication with the students. Furthermore, it is reasonable to create an interactive learning atmosphere. For example, the instructor can ask typical questions at the appropriate time and let the students discuss in a group model, after the results are obtained, they can be discussed again between the groups. Get the correct answer and give it to the teacher. Let each student participate in and experience the fun. ${ }^{[8]}$

\subsection{China's Universities and Colleges Should Strengthen the Cultivation of All-round Talents}

In traditional English language education, most of them focus on practicing the writing of students, while ignoring their practical application. At the same time, the instructor only focuses on the knowledge points of the exam, but does not have an important understanding of the practical skills and abilities of the English language. Based on this situation, if you want to cultivate a comprehensive talent, you must break through the previous teaching model. Universities and colleges can refer to the construction theory and highlight the students' actual knowledge exchange. And teachers can carry out effective reforms according to the content of the textbooks and the way of teaching, and even adapt the textbooks according to actual conditions, because constructivism is of great significance to China's current reform of traditional education models. If China's universities and colleges use this theory reasonably and effectively, discard the shortcomings of traditional education and change its teaching methods and models, it can effectively improve the students' comprehensive quality and professional ability. This situation is also the inevitable result of the change in China's English language teaching. ${ }^{[9]}$

\section{Conclusion}

In summary, the theory of constructivism is feasible. This theory has important reference significance for China's current education model. This theory can effectively stimulate students' enthusiasm for learning and break through the situation that traditional teachers occupy the dominant position and students are passive. Therefore, China's 
universities and colleges should apply the theory of construction to practical English language teaching, highlight the students' subjectivity in the classroom, strengthen the interaction of teaching in the classroom, and stimulate the creativity of students. And through the implementation of classroom activities, students can effectively stimulate the active learning effect, and enhance the cultivation of students' innovative ability and logical thinking. Based on this, students can be very interested in the English language and reduce the difficulty of the teaching content, so that the actual mastery of the English language is greatly improved, which lays a good foundation for the students' comprehensive quality and language use, and also builds confidence in their future entry into the workplace.

\section{References}

[1] Wenjun Gao. Exploration of the Role of Constructivism Learning Theory in English Reading Teaching in Higher Vocational Colleges And Its Enlightenment $[\mathrm{J}]$. Education for Chinese After-school (Theory), 2019(09):107. (in Chinese)

[2] Qiwei Yuan. College English Teaching Method under the Guidance of Constructivism Teaching Model[J]. Overseas English, 2019(04):150+152. (in Chinese)

[3] Yanping Zhang. Research on the Reform of College English Majors' Phonetic Teaching from the Per- spective of Constructivism[J]. Education Forum, 2019(02): 139-140. (in Chinese)

[4] Li Xie. Exploring the Innovation of English Teaching Methods in Higher Vocational Education from the Perspective of Constructivism[J]. Intelligence, 2018(32):150. (in Chinese)

[5] Meiling Li. Inspiration and Thinking on Constructivism Theory for College English and Linguistics Teaching[J]. Education Modelrnization, 2018, 5(37):129-130. (in Chinese)

[6] Hangfan Zhou. Exploration of English Linguistics Teaching from the Perspective of Constructivism[J]. Journal of Qiqihar Junior Teachers' College, 2018(03):136-137. (in Chinese)

[7] Juan Huang. Research on English Linguistics Teaching under Constructivism-Comment on "Introduction to English Linguistics"[J]. News and Writing, 2018(01):118. (in Chinese)

[8] Bin Li. Research on the Reform Strategy of English Linguistics Teaching Model Under the Theory of Constructivism[J]. Journal of Harbin Institute of Vocational Technology, 2016(02):134-136. (in Chinese)

[9] Zhixiong Wang, Juan Du. Research on the English Linguistics Classroom Construction Based on Constructivism[J]. Journal of Seeking Knowledge Guide, 2016(1):98-98. (in Chinese) 